
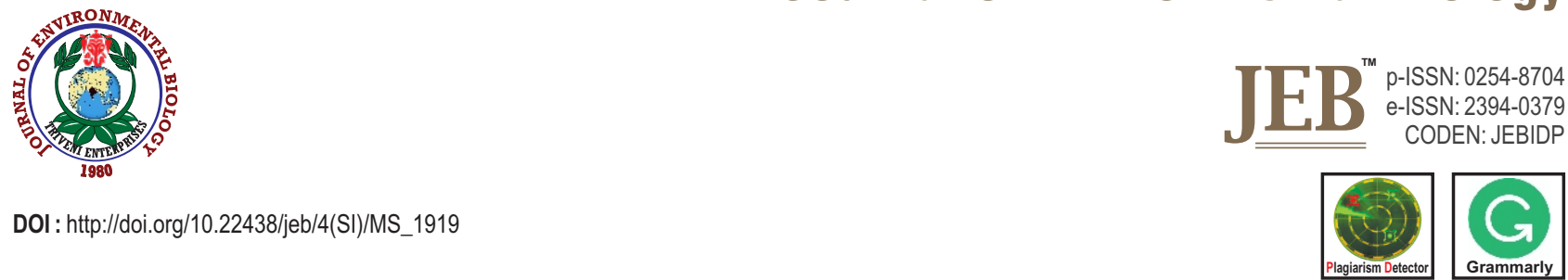

\title{
Study on the Amynthas (Kinberg, 1867) earthworm (Megascolecidae: Oligochaeta) diversity through DNA barcoding from Northeast India
}

\author{
M. Vabeiryureilai', C. Zothansanga ${ }^{1}$, M. Lalchhanhima ${ }^{1}$, N.S. Kumar ${ }^{2}$ and H. Lalthanzara* \\ ${ }^{1}$ Department of Zoology, Pachhunga University College, Aizawl-796 001, India \\ ${ }^{2}$ Department of Biotechnology, Mizoram University, Aizawl-796 001, India \\ *Corresponding Author Email : hzara.puc@gmail.com
}

\begin{abstract}
Aim: To study species diversity of Amynthas (Kinberg, 1867) earthworm from Northeast India using mitochondrial CO1 gene by DNA sequencing.

Methodology: Earthworms were collected from different habitats of Northeast states of India. Morphological identification upto the genus was performed. Genomic DNA was extracted by CTAB method followed by PCR amplification of mtDNA CO1 gene. The amplicons obtained were sequenced by AB3500 Genetic Analyzers.

Results: A total of 2355 Amynthas species were collected from 361 different sampling sites from various habitats of north east India. Sequencing of mtDNA C01 marker followed by matching with BOLD system database confirmed the presence of ten different species of Amynthas earthworms such as Amynthas alexandri, A. corticis, A.diffringens, A. gracilis, A. hawayanus, $A$. hupeiensis, $A$. incongruus, $A$. morrisi, $A$. papulosus and $A$. robustus. The DNA sequence was submitted to NCBI GenBank. Among them, $A$. corticis was the most widely distributed species found in six states, followed by $A$. diffringens found in five states. A. incongruus was confined to Mizoram only and is a new record for the northeast region of India. Four species reported from Nagaland (A. alexandri, A. diffringens, $A$. gracilis, $A$. morrisi) are new records for the state, $A$. diffringens was new to Meghalaya, and $A$. hawayanus, $A$. incongruus and $A$. populosus were new records for the state of Mizoram. A. hupeiensis was a new record for Assam.

Interpretation: Based on the molecular analysis of mtDNA CO1 sequences, we have reported five newly recorded species for Nagaland, three for Mizoram and one each for Meghalaya and Assam states. Our results indicated the species richness of Amynthas earthworms. Many more species of Amynthas earthworms are yet to be contributed towards the species richness from Northeast India.

Earthworm sampling from eight Northeastern States of India. Specimens- fix \& preserved in $100 \%$ ethanol and later $4 \%$ farmalin. Morpho-anatomical study for Genus Amynthas confirmation

Genomic DNA extraction from body tissue by CTAB method \& PCR amplification using CO1 marker Sanger Sequencing by AB3500 Genetic Analyzers MEGA-X, MrBayes Software

$10 \mathrm{sp}$. of Amynthas identified (>97\% similarity) after BLAST in BOLD System \& NCBI GenBank). Such as ilis, $A$. hawayanus, $A$. corticis, $A$. diffringens, A. gracmorrisi, $A$. papulosus, \& $A$. robustus. Sequences submitted to NCBI GenBank.
\end{abstract}

Key words: Amynthas, DNA sequencing, Earthworms, Genetic diversity, Northeast India

How to cite : Vabeiryureilai, M., C. Zothansanga, M. Lalchhanhima, N.S. Kumar and H. Lalthanzara: Study on the Amynthas (Kinberg, 1867) earthworm (Megascolecidae: Oligochaeta) diversity through DNA barcoding from Northeast India. J. Environ. Biol., 41, 867-873 (2020). 


\section{Introduction}

Earthworms are mostly terrestrial oligochaetes (Annelida: Clitellata) which contribute about $80 \%$ of total soil invertebrate biomass (Nainawat and Nagendra, 2001). From the globally estimated 6500 species of earthworms, only 3500 species have been described (Fragoso et al., 1997). Dispersal of earthworms is usually uneven (Singh et al., 2016) and their numbers varies according to type of soil (Curry, 1998) as well as ecological features, especially edaphic factors such as moisture and temperature (Kaleemurrahman and Ismael, 1981) and availability of organic matter in the soils (Namita and Swati, 2009). Recently, a metadata analysis has revealed that earthworm species diversity is higher in temperate region compared to tropical regions (Phillips et al., 2019).

Amynthas (Kinberg, 1867) are group of earthworms classified under family megascolecidae (Oligochaeta: Annelida) comprise large number of species. The morphological features of earthworm species can be distinguished based on features like position and shape of clitellum, position of genital organs, number and arrangement of setae, position and number of spermathecal pores, dorsal pores, etc., (Stephenson, 1923; Gates, 1972; Sims and Easton, 1972; Julka, 1988). Morphologically, the genus Amynthas is characterized by annular clitellum in 14-16 segments, epilobous prostomium, three pairs of spermathecal pores in 5/6-7/8, first dorsal pore at 10/11 or at 11/12 in few specimens, single mid-ventral female pore at 14 segment, male pores are small circular pair at 18 segment, lateral to one or more pairs of post-setal small genital markings (small discs) (Stephenson, 1923; Gates, 1972). Amynthas earthworms can be recognized by a light-colored, smooth annular type of clitellum (Schult et al., 2016). The BOLD system database has recorded 2,031 specimens and classified 185 different species of Amynthas (http://v3.boldsystems.org). China alone is known to harbor 302 Amynthas species (Sun, 2013). Amynthas earthworms are found in forests as well as local patchy soil with density >50 individuals per m2 (Gorres and Melnichuk, 2012). Amynthas are epi-endogeic worms that live underneath litter or in topsoil, whereby they alter the soil texture and eliminate organic materials from the soil surface (Archer, 2012; Gorres and Melnichuk, 2012; Greiner et al., 2012; Ikeda et al., 2015).

A significant number of new species are described every year. Due to proliferation of taxonomic descriptions of new species, distinctive morphological characteristics are not apparent at the species level and many cryptic species have been noted. For instance, recently a considerable number of redescription of earthworm species have been recorded for several taxa (Zhao et al., 2017; Azama and Ishizuka, 2018; Hong et al., 2018; Bozorgi et al., 2019; Csuzdi et al., 2019). Therefore, molecular intervention can serve as the only key to solve species validation (Blakemore, 2013). In India, 590 earthworm species and subspecies belonging to 67 genera have been recorded (Julka et al., 2009). The extent of earthworm diversity in Northeastern India has also been reported by various researchers from different states such as Meghalaya (Mishra and Ramakrishnan, 1988; Halder, 1999; Kharkongor, 2018), Manipur (Haokip and Singh, 2012), Mizoram (Ramanujam et al., 2004), Assam (Rajkhowa et al., 2015), Tripura (Chaudhuri, 2012), Arunachal Pradesh (Julka, 1976; 1981; Halder, 2007), Nagaland (Thyug and Kakati, 2018) and a few diversity survey records from Sikkim (Soota and Halder, 1981, Subedi and Saxena, 2018; Subedi et al., 2018a,b,c). However, no report on Amynthas species diversity based on the genetic diversity has been documented from this part of the Indo-Myanmar biodiversity hotspot region. Therefore, in lieu of the above, an attempt was made to characterize genetic diversity of Amynthas earthworms from north-east India.

\section{Materials and Methods}

The study area included all states of North-eastern India, i.e., Arunachal Pradesh, Assam, Manipur, Meghalaya, Mizoram, Nagaland, Sikkim and Tripura as shown in Fig.1. The northeastern region of India covers 2,62,379 km area (Rodgers and Panwar, 1988) is located between $22^{\circ} \mathrm{N}$ and $29^{\circ} 5^{\prime} \mathrm{N}$ latitude and $88^{\circ} \mathrm{E}$ and $97^{\circ} 30^{\prime} \mathrm{E}$ longitude and shares an international border with Bangladesh and Bhutan, China and Myanmar. In Northeast India, there are 28 National Parks of national as well as international importance. The region represents an important part of Indo-Myanmar biodiversity hotspot, one of the 25 global biodiversity hotspots (Chatterjee et al., 2006) and the eastern part of Himalayan Biodiversity hotspot.

The study was conducted between $20^{\text {th }}$ May and $30^{\text {th }}$ August, 2018. The earthworms were collected from the study sites by random method hand-sorting as well as opportunistic sampling was carried out from various sites, including house garden, forest, roadside, side drains, sewage disposal and grasslands of north eastern states (Fig. 1). Morphological identification of earthworms was performed in the Research and Instrumentation Centre, Department of Zoology, Pachhunga University College in consultation with earthworm taxonomic monographs (Stephenson, 1923; Gates, 1972; Julka, 1988) and studied under a stereo-zoom microscope (Optika SZN 8 with Optikam Pro 8 LT). The number of earthworms collected and the environmental variables were recorded and the specimens were preserved in $100 \%$ ethanol for further identification.

Specimens identified as Amynthas species were subjected to molecular characterization. Genomic DNA was extracted from the tissues of posterior part by using Cetyltrimethylammonium bromide method (Murray and Thompson, 1980). Molecular identification of earthworms was performed by using cytochrome $c$ oxidase subunit (CO1) gene (forward primer LC01490 5'- GGTCAACAAATCA TAAAGATATTGG - 3', reverse primer HCO2198 5'TAGAATTAGAAGATCAACCAG - 3') (Folmer et al., 1994). PCR reaction was prepared for $25 \mu$ l volumes which contained $0.8 \mu$ l (80 ng) DNA template, $12.5 \mu \mathrm{l}$ PCR Master Mix (Takara Tlontekh), $11 \mu \mathrm{l}$ nuclease-free water and $10 \mathrm{pmol}(1 \mu \mathrm{l})$ of each - primer. PCR cycling consisted of an initial denaturation step at $94^{\circ} \mathrm{C}$ for 4 mins. 
followed by 35 cycles for $1 \mathrm{~min}$. at $94^{\circ} \mathrm{C}, 1 \mathrm{~min}$. at $49^{\circ} \mathrm{C}$ and $1 \mathrm{~min}$. at $72^{\circ} \mathrm{C}$. And the last extension step was done at $72^{\circ} \mathrm{C}$ for 10 mins. The amplified products were checked in $1.5 \%$ agarose gel electrophoresis stained with Invitrogen SYBR Safe, with 100 bp DNA ladder as a marker. Sequencing was done by using 3500 Genetic Analyzer 8ch RUO, model no. 622-0100 (Thermo Fisher Scientific). DNA sequences were aligned, edited and analyzed using BLAST (Altschul et al., 1990) and Bioedit sequence alignment editor (Hall, 1999). The DNA sequences were submitted to GenBank, NBCl.

\section{Results and Discussion}

In all, 2,355 earthworms were identified through morphological examination as Amynthas species (Megascolecidae). They were collected from 361 different sites of eight north-eastern states of India. The identified species were further confirmed by DNA sequencing. The analysis of generated
DNA sequences revealed that 52 individuals belonged to 10 different species and the remaining specimens were further subjected to detail morpho-anatomical and molecular study. The nucleotide sequences of Amynthas were submitted to GenBank (NCBI) and their accession number were $A$. alexandri (MN151381), A. corticis (MT438695), A. diffringens (MT444902), A. gracilis (Mh191377), A. hawayanus (MT444905), A. hupeiensis (MT444908), A. incongruus (MT444907), A. morrisi (MT444903), A. papulosus (MT444906) and A. robustus (Mt444904) (Table 1). This study provides effective tool for identification of earthworm species based on mtDNA COI gene. For 52 Amynthas species identified, $99.9 \%$ of the COI identifications agreed with the morphological identifications by expert taxonomists. It was reported that over $98 \%$ of animal species show greater than $2 \%$ divergence and suggested that this was the threshold for spider identification (Hebert et al., 2003). The estimated value of the shape parameter for the discrete Gamma Distribution is 0.2139 . The substitution pattern

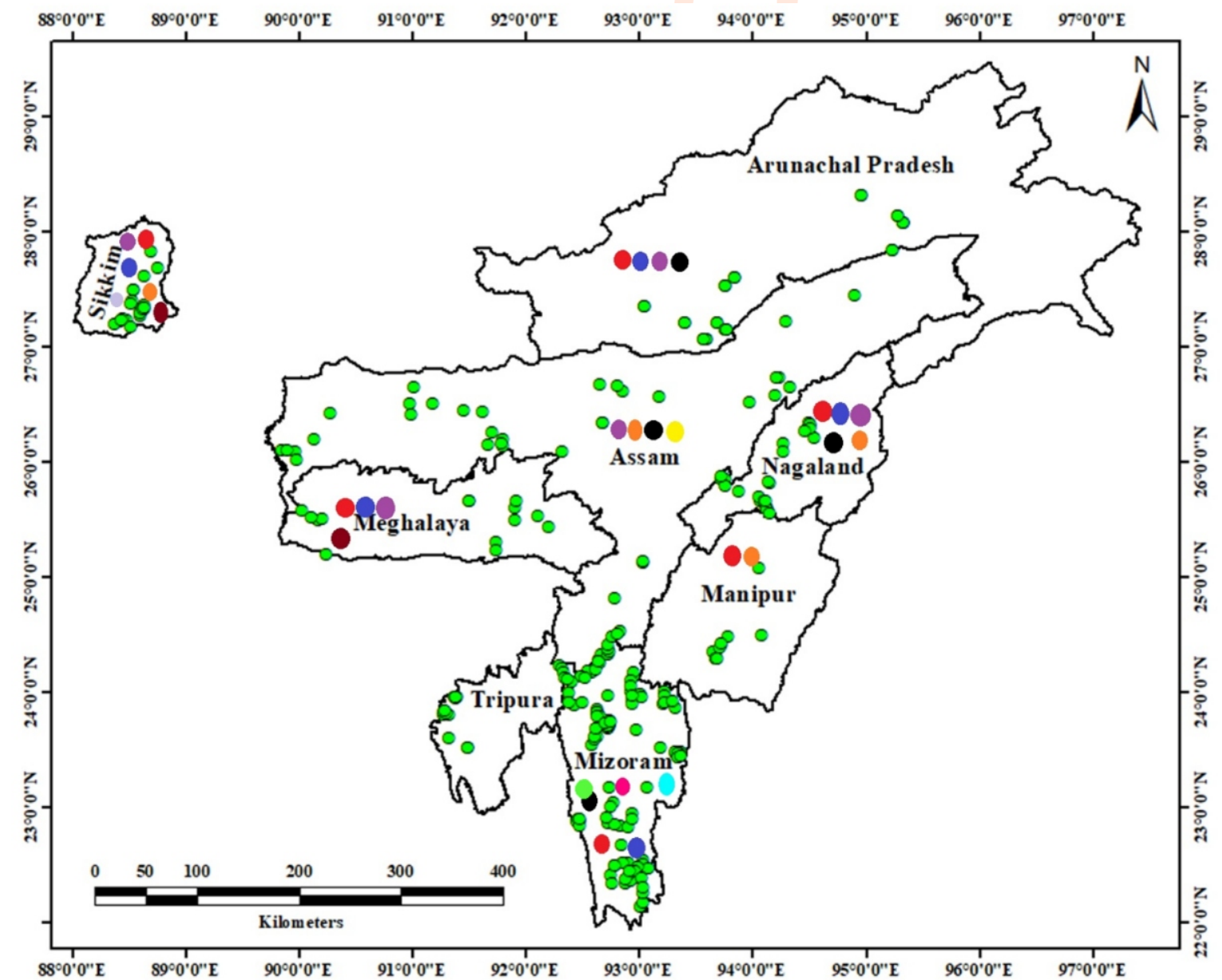

Fig. 1: Map of Northeast states showing collection sites along with their particular species found in each location indicating various colour codes: - A.corticis, A. gracilis, A. diffringens, A.morrisi, A.alexandri, A.robustus, A. hawayanus, A.papulosus, A. incongruus and A. hupeiensis. 
Table 1: Genetically identified Amynthas species of Northeast India

\begin{tabular}{|c|c|c|c|c|c|c|c|c|c|}
\hline Amynthas species & AP & AS & MN & MG & MZ & NG & SK & TR & Accession No. \\
\hline alexandri & & + & & & + & $t^{*}$ & & + & Mn151381 \\
\hline corticis & + & & + & + & + & + & + & & Mt438695 \\
\hline diffringens & + & + & & $t^{*}$ & & $t^{*}$ & + & & Mt444902 \\
\hline gracilis & + & & & + & + & $t^{*}$ & + & & Mh191377 \\
\hline hawayanus & & & & & $t^{*}$ & & + & & Mt444905 \\
\hline hupeiensis & & $t^{*}$ & & & & & & & Mt444908 \\
\hline incongruus & & & & & $t^{*}$ & & & & Mt444907 \\
\hline morrisi & & + & + & & & $t^{*}$ & + & & Mt444903 \\
\hline papulosus & & & & + & $t^{*}$ & & & & Mt444906 \\
\hline robustus & & & & + & & & + & & Mt444904 \\
\hline
\end{tabular}

*New report from this location: AP (Arunachal Pradesh), AS (Assam), MN (Manipur), MG (Meghalaya), MZ (Mizoram), NG (Nagaland), SK (Sikkim), and TR (Tripura)

Table 2: Matrix of percentage pairwise nucleotide divergences with K2P distance on cytochrome c oxidase subunit I (COI) within Amynthas species

\begin{tabular}{|c|c|c|c|c|c|c|c|c|c|c|c|c|}
\hline \multirow{2}{*}{ Species } & \multirow{2}{*}{$\begin{array}{l}\text { NCBI } \\
\text { Acc. No. }\end{array}$} & \multicolumn{11}{|c|}{ K2P-distance } \\
\hline & & 1 & 2 & 3 & 4 & 5 & 6 & 7 & 8 & 9 & 10 & 11 \\
\hline N. aibuhitensis_1 & & & 0.030 & 0.027 & 0.027 & 0.026 & 0.030 & 0.026 & 0.029 & 0.026 & 0.023 & 0.027 \\
\hline A. alexandri_2 & МT357030 & 0.338 & & 0.021 & 0.021 & 0.021 & 0.022 & 0.020 & 0.022 & 0.020 & 0.021 & 0.021 \\
\hline A. corticis_3 & MT438695 & 0.276 & 0.238 & & 0.000 & 0.019 & 0.022 & 0.017 & 0.022 & 0.020 & 0.017 & 0.018 \\
\hline A. diffringens_4 & MT444902 & 0.276 & 0.238 & 0.000 & & 0.019 & 0.022 & 0.017 & 0.022 & 0.020 & 0.017 & 0.018 \\
\hline A. gracilis_5 & MH191377 & 0.323 & 0.214 & 0.178 & 0.178 & & 0.019 & 0.019 & 0.020 & 0.017 & 0.017 & 0.020 \\
\hline A. hawayanus_6 & MT444905 & 0.337 & 0.215 & 0.212 & 0.212 & 0.199 & & 0.021 & 0.018 & 0.020 & 0.020 & 0.018 \\
\hline A. hupeiensis_7 & MT444908 & 0.263 & 0.195 & 0.147 & 0.147 & 0.181 & 0.190 & & 0.022 & 0.018 & 0.016 & 0.017 \\
\hline A. incongruus_8 & MT444907 & 0.311 & 0.226 & 0.209 & 0.209 & 0.200 & 0.171 & 0.200 & & 0.021 & 0.021 & 0.020 \\
\hline A. morrisi_9 & MT444903 & 0.302 & 0.212 & 0.191 & 0.191 & 0.165 & 0.208 & 0.191 & 0.215 & & 0.016 & 0.019 \\
\hline A. papulosus_10 & MT444906 & 0.266 & 0.192 & 0.149 & 0.149 & 0.165 & 0.182 & 0.145 & 0.181 & 0.148 & & 0.018 \\
\hline A. robustus_11 & MT444904 & 0.309 & 0.207 & 0.177 & 0.177 & 0.203 & 0.159 & 0.164 & 0.171 & 0.207 & 0.180 & \\
\hline
\end{tabular}

The estimated value of the shape parameter for the discrete Gamma Distribution is 0.2139 . Substitution pattern and rates were estimated under the Tamura (1992) model ( $+G)[1]$. The nucleotide frequencies are $A=29.86 \%, T / U=29.86 \%, C=20.14 \%$, and $G=20.14 \%$. The maximum Log likelihood for this computation was -2678.989 . This analysis involved 10 nucleotide sequences. Codon positions included were $1 \mathrm{st}+2 \mathrm{nd}+3 \mathrm{rd}+$ Noncoding. There was a total of 557 positions in the final dataset. Evolutionary analyses were conducted in MEGAX.

and rates were estimated under the Tamura (1992) model $(+G)$. There were 557 positions in the final dataset coded with 209 amino acids. The sequences analysis revealed that $64 \%$ sequences were conserved regions as well as $36 \%$ variable sites with $24 \%$ parsimony information within the Amynthas.

The most variable sites among species were found to be 506-515 nucleotide regions, which signified different species for 10 variants (Fig. 2). The sequence analysis using DnaSP 6 software revealed that there were 10 haplotypes and haplotype diversity was 1.0 within the genus (Rozas et al., 2017). Thus, the sequences amplified using mtDNA CO1 gene-specific primers identified 10 different species such as $A$. corticis (Kinberg, 1867), A. diffringens (Baird, 1869), A. hupeiensis (Michaelsen, 1895), $A$. morrisi (Beddard, 1892), A. alexandri (Beddard, 1900), A. robustus (Perrier, 1872), A. hawayanus (Rosa, 1891), A. papulosus (Rosa, 1896), and $A$. incongruus (Chen, 1933) (Table 1). The nucleotide frequencies are $A=29.86 \%, T / U=29.86 \%, C=$ $20.14 \%$, and $\mathrm{G}=20.14 \%$. The Kimura 2 parameter (K2P) genetic distance between $N$. aibuhitensis and other Amynthas were $A$. alexandri (33.8\%), A. corticis (27.6\%), A. diffringens (27.6\%), $A$. gracilis (32.3\%), A. hawayanus (33.7\%), A. hupeiensis (26.3\%), A. incongruus (31.1\%), A. morrisi (30.3\%), A. papulosus $(26.6 \%)$ and $A$. robustus $(30.9 \%)$. The K2P distance revealed that Amythas species were different from each other forming a monophyletic clade (Table 2, Fig. 3). Ten species of Amynthas showed that their genetic diversity located with their variable site at a particular nucleotide sequence (Fig. 3). Amynthas were isolated from an out-group (Nereis aibuhitensis) even though all these species belong to the same phylum. This result showed that the identified Amynthas in north-eastern India were different from each other, based on the genetically distinct populations from nucleotide sequences (Fig. 2). The levels of evolutionary divergence between sequences were obtained by a bootstrap procedure (1000 generates). The evolutionary divergence between Amynthas species ranged from 0.0018 to 0.25827 , indicating that these species were different from each other (Table 2). 


\begin{tabular}{l|l} 
1. A.alexandri & CCTTCTACTT \\
\hline 2. A.corticis & ACTACTTCTA \\
\hline 3. A.diffringens & ACTACTTCTA \\
\hline 4. A.gracilis & TCTACTATTA \\
\hline 5. A.hawayanus & ATTATTATIA \\
\hline 6. A.hupeiensis & ACTACTACTA \\
\hline 7. A.incongruus & AACCCCCCAA \\
\hline 8. A.morrisi & CCTCCTTCTG \\
\hline 9. A.papulosus & TCTTCTACTA \\
\hline 10. A.robustus & CCTCCTACTA
\end{tabular}

Fig. 2: Fragment of most variable site within 557 bp nucleotide sequences of mitochondrial $\mathrm{CO} 1$ gene, which signifies different species for a number of 10 variants identified within Amynthas.

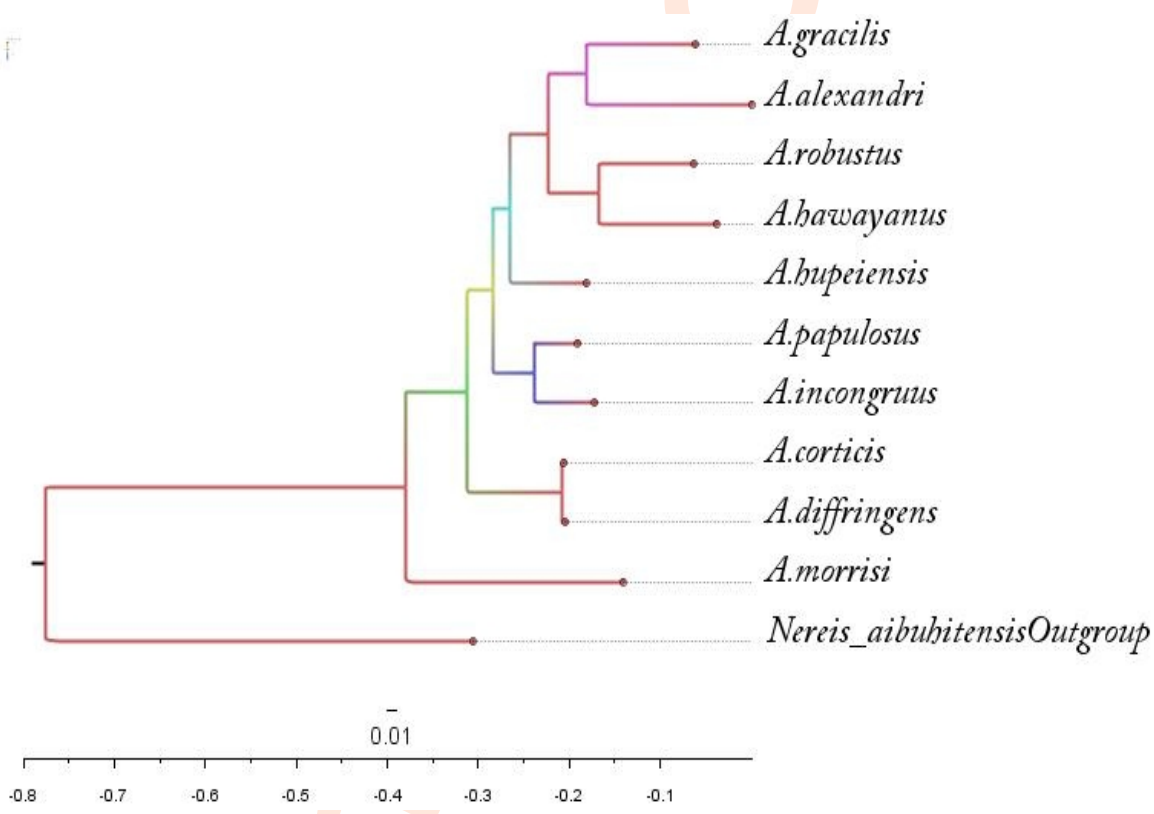

Fig. 3: Neighbour-joining phylogenetic tree based on K2P distances from $557 \mathrm{bp} \mathrm{mtDNA} \mathrm{COI} \mathrm{gene} \mathrm{sequences} \mathrm{of} \mathrm{Amynthas} \mathrm{species.} \mathrm{NJ} \mathrm{tree} \mathrm{was}$ calculated in Mr Bayes based on the GTR+I+R with bootstrap values from 20000 replicates $(p<0.01)$.

The distribution pattern of Amynthas species identified from this study revealed that state-wise, both Mizoram and Sikkim harboring six different known species had the highest species diversity, followed by Meghalaya and Nagaland with five species each (Fig.1). A. corticis was the most versatile species found in six states, followed by $A$. diffringens found in five states (Table 1). Halder et al. (2007) also recorded A. diffringens from five states of north-east India. Soota and Halder (1981) had reported the presence of $A$. diffringens, $A$. hawayanus and $A$. morrisi and
Subedi et al. (2018b) reported $A$. gracilis, A. robustus and $A$. corticis from Sikkim. Kharkongor (2018) had recorded A. cortices, A. gracilis, A. papulosus and A. robustus from Meghalaya. Halder et al. (2007) also reported A. morrisi from Meghalaya. Ramanujam et al. (2004) had reported the presence of $A$. alexandri and $A$. corticis from Mizoram. Similarly, Haokip and Singh (2012) recorded two species (A. cortices and $A$. morrisi) in Manipur state. A. diffringens is the only Amynthas species recorded by Julka (1976) as Pheretima diffringens (its homotypic 
synonym) from Arunachal Pradesh. Thyug and Kakati (2018) recorded $A$. corticis and one unidentified Amynthas species from Nagaland. Tripura harbored the lowest diversity with only one reported species ( $A$. alexandri). Even though Tripura has a good number of earthworm species, however, out of 38 recorded earthworm species only $A$. alexandri has been reported from the genus Amynthas (Chaudhuri et al., 2012). A. robustus has been reported from Meghalaya by Halder et al. (2007) and from Sikkim by Subedi et al. (2018c).

This study reported new records for some states of northeastern India. Four species of Amynthas are new record from Nagaland, viz., A. diffringens, A. gracilis, A. morrisi and $A$. alexandri; one species from Meghalaya i.e. $A$. diffringens; four species from Mizoram viz., $A$. hawayanus, $A$. incongruus, $A$. alexandri and $A$. papulosus. In addition to the present record of ten species, many mtDNA CO1 sequences of Amynthas earthworms that we have documented were below $97 \%$ similarity when compared to BOLD systems and NCBI databases. It can also be inferred from these studies that more species would be identified from this site in future. Hence, this study affirms the unique and rich diversity of Amynthas species found in this biodiversity hotspot region.

\section{Acknowledgments}

We express our gratitude to the NER-BPMC, Department of Biotechnology (DBT), New Delhi for financial assistance. We are grateful to the State Biodiversity Board of all north-eastern states for sampling permission. Special thanks to DBT Biotech Hub (Advance Level, BT/22/ NE/2011, Dated: July 19, 2017)), Pachhunga University College, Aizawl and Bioinformatics Infrastructure Facility (BT/BI/12/060/2012, NERBIFMUA), Mizoram University, Aizawl.

\section{References}

Altschul, S.F., W. Gish, W. Millers, E.W. Myers and D.J. Lipman: Basic local alignment search tool. J. Mol. Biol., 215, 403-410 (1990).

Archer, K.L.: The introduction of exotic earthworms by European colonists; Impact on agriculture and forestry: the earthworm invasion. Megadrilogica, 15, 212-214 (2012).

Azama, Y. and K. Ishizuka: Three new earthworm species of the genus Amynthas (family Megascolecidae) from northern mountainous part of Okinawajima Island, Japan. Edaphologia, 103, 25-32 (2018).

Blakemore, R.J.: Earthworms newly from Mongolia (Oligochaeta, Lumbricidae, Eisenia). ZooKeys, 285, 1-21 (2013).

Bozorgi, F., M. Seiedy, M. Malek, M. Aira, M. Pe'rez-Losada and J. Domınguez: Multigene phylogeny reveals a new Iranian earthworm genus (Lumbricidae: Philomontanus) with three new species. PLOS ONE 14, e0208904 (2019).

Chatterjee, S., A. Saikia, P. Dutta, D. Ghosh, G. Pangging and A.K. Goswami: Biodiversity Significance of North East India. Forests Conservation Programme, New Delhi. pp. 7-8 (2006).

Chaudhuri, P. S., D. Animesh, B. Gautam and N. Sabyasachi: Earthworm diversity in Tripura-present status. Curr. Sci., 78, 343-346 (2012).

Curry, J.P.: Factors affecting earthworm abundance in soils. In: Earthworm Ecology (Ed.: C.A. Edwards). St. Lucie Press, Boca
Raton, Florida. pp. 37-64 (1998).

Csuzdi, C., E. Rota, T. Szederjesi, E. Sherlock, G.G. Brown, C.H. Chang, D.D. Cosin, C. Fragoso, B.G.M. Jamieson, Y. Hong, S.W. James, M.G. Paoletti, T. Pavlícek, D. Plisko, V.V. Pop and H.P. Shen: Description of a new Central African earthworm, Petroscolex centenarius gen. et sp. nov. (Crassiclitellata, Eudrilidae), celebrating the 100th birthday of Pietro Omodeo. Zootaxa, 4674, 501-508 (2019).

Folmer, O., M. Black, W. Hoeh, R. Lutz and R. Vrijenhoek: DNA primers for amplification of mitochondrial cytochrome $\mathrm{c}$ oxidase subunit I from diverse metazoan invertebrates. Mol. Mar. Biol. Biotech., 3 , 294-249 (1994).

Fragoso, C., G.C. Brown, J.C. Parton, E. Blanchart, P. Lavelle, B. Pashanasi, B. Senapati and T. Kumar: Agricultural intensification, soil biodiversity and agroecosystem function in the tropics: The role of earthworms. Appl. Soil Ecol., 6, 17-35 (1997).

Gates, G.E.: Burmese earthworms: An introduction to the systematics and biology of megadrile oligochaetes with special reference to SoutheastAsia. Trans. Am. Philos. Soc., 62, 1-326 (1972).

Görres, J.H. and R.D. Melnichuk: Asian invasive earthworms of the genus Amynthas Kinberg in Vermont. North. Nat., 19, 313-322 (2012).

Greiner, H.G., D.R. Kashian and S.D. Tiegs: Impacts of invasive asian (Amyntha shilgendorfi) and European (Lumbricus rubellus) earthworms in a North American temperate deciduous forest. Biol. Inv., 14, 2017-2027 (2012).

Halder, K.R., S. Dhani and C.K. Mandal: On some earthworms present in the unnamed collections of Zoological Survey of India. Rec. Zool. Surv. India, 107, 79-93 (2007).

Halder, K.R.: Oligochaeta: Earthworm: In state fauna series 4: Fauna of Meghalaya Part 9 (Calcutta: Zoological Survey of India), pp. 393439 (1999)

Hall, T.A.: BioEdit: A user-friendly biological sequence alignment editor and analysis program for Windows 95/98/NT. Nucleic Acids Symp. Ser., 41, 95-98 (1999).

Haokip, S.L. and T.B. Singh: Diversity and distribution of earthworms in a natural reserved and disturbed subtropical forest ecosystem of Imphal-West, Manipur, India. Int. Multidis. Res. J., 2, 28-34 (2012).

Hebert, P.D.N, A. Cywinska, S.L. Ball and J.R. deWaard: Biological identifications through DNA barcodes. Proc. R. Soc. Lond. B, 270, 313-321 (2003).

Hong, Y., K. Inkhavilay and S.W. James: Nine new species of the "aeruginosus"-group in Amynthas (Clitellata: Megascolecidae) from Nam Et-Phouley National protected Area, Laos. Zootaxa, 4496, 238-250 (2018).

Ikeda, H., M.A. Callaham Jr, J.J. O'Brien, B.S. Hornsby and E.S. Wenk: Can the invasive earthworm, Amynthas agrestis, be controlled with prescribed fire? Soil Biol. Biochem., 82, 21-27 (2015).

Julka, J.M., R. Paliwal and P. Kathireswari: Biodiversity of Indian earthworms- An overview. In: Proceedings of Indo-US Workshop on Vermitechnology in Human Welfare (Eds.: C. A. Edwards, R. Jayaraaj and I. A. Jayraaj). Rohini Achagam, Coimbatore, India, pp. 36-56 (2009).

Julka, J.M.: Fauna of India and the Adjacent Countries: Megadrile Oligochaeta (Earthworms). Haplotaxida: Lumbricina: Megascolecoidea: Octochaetidae. Zoological Survey of India. Kolkata, India (1988).

Julka, J.M.: Studies on the earthworms collected during the Daphabum expedition in Arunachal Pradesh, India. Rec. Zool. Surv. Ind., 69, 229-239 (1976).

Julka, J.M.: Taxonomic studies on the earthworms collected during the Subansiri Expedition in Arunachal Pradesh, India Subansiri Expedition (1974-1975). Occasional paper No. 26. ZSI, Kolkata, pp 1-53(1981). 
Kaleemurrahman, M. and S.A. Ismail: Earthworm: An index of the physical nature of the soil. In: Progress in Soil biology and Ecology in India (Ed.: Veeresh, GK) Univ. Agri. Sci., Bangalore, pp. 60-63 (1981).

Kharkongor, I.J.: Taxonomic and ecological studies on the earthworms (Annelida: Oligochaeta) of West Khasi Hills District, Meghalaya Rec. Zool. Surv. Ind., 118, 56-74 (2018).

Kumar, S., G. Stecher, M. Li, C. Knyaz and K. Tamura: MEGA X: Molecular Evolutionary Genetics Analysis across computing platforms. Mol. Biol. Evol., 35, 1547-1549 (2018).

Mishra, K.C. and P.S. Ramakrishnan: Earthworm population dynamics in different jhum fallows developed after slash and burn agriculture in north-eastern India. Proc: Animal Sci., 97, 309-318 (1988).

Murray, M.G. and W.F. Thompson: Rapid isolation of high molecular weight plant DNA. NucleicAcids Res., 8, 4321-4325 (1980).

Nainawat, R. and B. Nagendra: Density and distribution of earthworms in different localities of Jaipur. J. Eco-physiol., 4, 9-13 (2001).

Namita J. and A. Swati: Diversity and distribution of earthworms in a subtropical forest ecosystem in Uttarakhand, India. The Nat. Hist. J. Chulalongkorn Univ., 9, 21-25 (2009).

Phillips, H.R.P., C.A. Guerra, M.L.C. Bartz, M.J. I. Briones, G. Brown, T.W. Crowther, O.Ferlian, K.B. Gongalsky, J. van den Hoogen, J. Krebs, A. Orgiazzi, D. Routh, B. Schwarz, E.M. Bach, J. Bennett, U. Brose, T. Decaëns, B. König-Ries, M. Loreau, J. Mathieu, C. Mulder, W.H. van der Putten, K.S. Ramirez, M.C. Rillig, D. Russell, M. Rutgers, M.P. Thakur, F.T. de Vries, D.H. Wall, D.A. Wardle, M. Arai, F.O. Ayuke, G.H. Baker, R. Beauséjour, J.C. Bedano, K. Birkhofer, E. Blanchart, B. Blossey, T. Bolger, R.L. Bradley, M.A. Callaham, Y. Capowiez, M.E. Caulfield, A. Choi, F.V. Crotty, A. Dávalos, D.J.D. Cosin, A. Dominguez, A.E. Duhour, N.vanEekeren, C.Emmerling, L.B. Falco, R. Fernández, S.J. Fonte, C. Fragoso, A.L.C. Franco, M. Fugère, A.T. Fusilero, S. Gholami, M.J. Gundale, M.G. López, D.K. Hackenberger, L.M. Hernández, T. Hishi, A.R. Holdsworth, M. Holmstrup, K.N. Hopfensperger, E.H. Lwanga, V. Huhta, T.T. Hurisso, B.V. lannone III, M. lordache, M. Joschko, N. Kaneko, R. Kanianska, A.M. Keith, C.A. Kelly, M.L. Kernecker, J. Klaminder, A.W. Koné, Y. Kooch, S.T. Kukkonen, H. Lalthanzara, D.R. Lammel, L.M. Lebedev, Y. Li, J.B.J. Lidon, N.K. Lincoln, S.R. Loss, R. Marichal, R. Matula, J.H. Moos, G. Moreno, A. Morón-Ríos, B. Muys, J. Neirynck, L. Norgrove, M. Novo, V. Nuutinen, V. Nuzzo, M. Rahman P, J. Pansu, S. Paudel, G. Pérès, L. Pérez-Camacho, R. Piñeiro, J-F Ponge, M.I. Rashid, S. Rebollo, J. Rodeiro-Iglesias, M.Á. Rodríguez, A.M. Roth, G.X. Rousseau, A. Rozen, E. Sayad, L.v. Schaik, B.C. Scharenbroch, M. Schirrmann, O. Schmidt, B. Schröder, J. Seeber, M.P. Shashkov, J. Singh, S.M. Smith, M. Steinwandter, J.A. Talavera, D. Trigo, J. Tsukamoto, A.W. de Valença, S.J. Vanek, I. Virto, A.A.Wackett, M.W. Warren, N.H. Wehr, J.K. Whalen, M.B. Wironen, V. Wolters, I.V. Zenkova, W. Zhang, E.K. Cameron and N. Eisenhauer: Global distribution of earthworm diversity. Science, 366, 480-485 (2019).

Rajkhowa, D. J., P.N. Bhattacharyya, A.K. Sharma and K. Mahanta: Diversity and distribution of earthworms in different soil habitats of
Assam, North-east India, an Indo-Burma biodiversity hotspot. Proc. Nat. Acad. Sci., Sec B: Biol. Sci., 85, 389-396 (2015).

Ramanujam, S.N., H. Lalthanzara and L.K. Jha: Biodiversity of earthworms in Mizoram. J. Nat. Con., 16, 129-134 (2004).

Rodgers, W.A. and H.S. Panwar: Planning a wildlife protected area network in India. Vol. 2, Project FO: IND/82/003. FAO, Dehradun, India, pp. 1-339(1988)

Rozas, J., A. Ferrer-Mata, J.C. Sánchez-DelBarrio, S. Guirao-Rico, P. Librado, S.E. Ramos-Onsins and A. Sánchez-Gracia: DnaSP 6: DNA sequence polymorphism analysis of large data sets. Mol. Biol. Evol., 34, 3299-3302 (2017).

Schult, N., K. Pittenger, S. Davalos and D. McHugh: Phylogeographic analysis of invasive Asian earthworms of the genus Amynthas in the Northeast United States. Invertebr. Biol., 135, 314-327 (2016).

Sims, R.W. and E.G. Easton: A numerical revision of the earthworm genus Pheretima (Megascolecidae: Oligochaeta) with the recognition of new genera and an appendix on the earthworms collected by the Royal Society North Borneo Expedition. Biol. J. Linn. Soc., 4, 169-268 (1972).

Singh, S., J. Singh and A.P. Vig: Effect of abiotic factors on the distribution of earthworms in different land use patterns. J. Basic Appl. Zool., $74,41-50$ (2016).

Soota, T.D. and K.R. Halder: On some earthworms from Eastern Himalayas. Rec. Zool. Surv. India, 79, 231-234 (1981).

Stephenson, J.: The Fauna of British India including Ceylon and Burma. Oligochaeta.: Taylor and Francis, London, p. 518 (1923).

Subedi, H.P. and R.M. Saxena: New record of earthworm Eukerria kuekenthali (Oligochaeta: Ocnerodrilidae) from Sikkim, India. J. Appl. Nat. Sci., 1, 250-252 (2018).

Subedi, H.P., R.M. Saxena and J.W. Reynolds: New record of an earthworm in the family Glossoscolecidae (Annelida: Oligochaeta) from Sikkim, India. Megadrilogica, 23, 51-56 (2018a).

Subedi, H.P., R.M. Saxena and J.W. Reynolds: New records of earthworm species Amynthas morrisi, Perionyx himalayanus and Perionyx jorpokriensis (Oligochaeta: Megascolecidae) from Sikkim, India. Megadrilogica, 23, 70-77 (2018b).

Subedi, H.P., R.M. Saxena and J.W. Reynolds: New earthworm (Oligochaeta: Octochaetidae) records of Dichogaster curgensis and Octochaetona beatrix from Sikkim. Megadrilogica, 23, 131139 (2018c).

Sun, J.: Taxonomy and Molecular Phylogeny of Amynthas earthworms from China. Shanghai Jiao Tong University. http://dx.doi.org/ 10.13140/RG.2.2.17529.67685(2013).

Tamura, K.: Estimation of the number of nucleotide substitutions when there are strong transition-transversion and $\mathrm{G}+\mathrm{C}$-content biases. Mol. Biol. Evol., 9, 678-687 (1992)

Thyug, L. and L.N. Kakati: Diversity and distribution of earthworms in a subtropical forest ecosystem of Mokokchung District, Nagaland, India. The Bioscan, 13, 775-779 (2018).

Zhao, G., M. Zhang, Y. Dong and J. Qu: New Species of Megascolecidae (Oligochaeta) from Hainan Island, China. Ann. Zool., 67, 221-227 (2017). 